2016

\title{
Big Fish, Small Sea: Big Companies in Small Towns
}

Christyne J. Vachon

Follow this and additional works at: https://open.mitchellhamline.edu/mhlr

Part of the Agriculture Law Commons, Land Use Law Commons, and the Property Law and Real Estate Commons

\section{Recommended Citation}

Vachon, Christyne J. (2016) "Big Fish, Small Sea: Big Companies in Small Towns," Mitchell Hamline Law Review. Vol. 42 : Iss. 4 , Article 4.

Available at: https://open.mitchellhamline.edu/mhlr/vol42/iss4/4

This Article is brought to you for free and open access by the Law Reviews and Journals at Mitchell Hamline Open Access. It has been accepted for inclusion in Mitchell Hamline Law Review by an authorized administrator of Mitchell Hamline Open Access. For more information, please contact sean.felhofer@mitchellhamline.edu. (c) Mitchell Hamline School of Law

\section{$\mathrm{MH}$} Mitchell | HAMUINE OPEN ACCESS selod of the mitchellhamline.edu 


\title{
BIG FISH, SMALL SEA: BIG COMPANIES IN SMALL TOWNS
}

\author{
Christyne J. Vachon ${ }^{\dagger}$

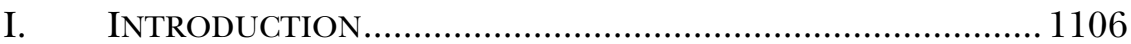

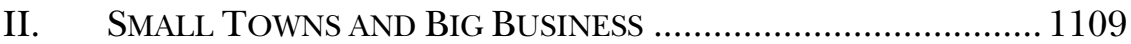 \\ A. Shopping in Small Towns and Rural Communities.......... 1109 \\ B. What Is It About the Big Fish and Little Sea? ................. 1111 \\ C. Does This Big Fish Really Stink? The Wal-Mart Effect and \\ Other Effects............................................................. 1113 \\ III. RECOMMENDATIONS FOR THE SMALL FISH AND SMALL SEA 1121 \\ A. General Recommendations: Some Tools in the Tackle Box.. 1121 \\ 1. Land Use Planning and Zoning ............................ 1123 \\ 2. Legislating to Protect Employees ................................ 1125 \\ 3. Being Flexible and Efficient................................. 1125

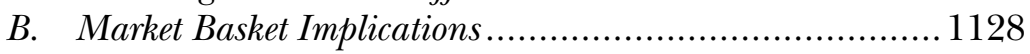

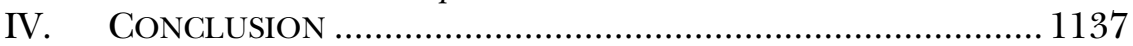

$\dagger \quad$ Christyne J. Vachon is a research fellow with the University of North Dakota School of Law, where she has also served as an assistant professor of law. She is currently based in Massachusetts, where she has conducted her research for this article. Her scholarship examines areas of interplay between business governance and ethics. She has practiced in for-profit and nonprofit law for large and small business entities. She would like to thank the University of North Dakota School of Law; Afra Afsharipour, Professor at UC Davis School of Law; and Joan Heminway, W.P. Toms Distinguished Professor at University of Tennessee College of Law for their comments on prior versions of this article. She also thanks Alexandra Sickler, Assistant Professor of Law at the University of North Dakota School of Law for brainstorming sessions. 


\section{INTRODUCTION}

It is not that I don't have a fear of sharks, it is that I have a respect for them, so that I know any more than if I were to go into the jungle, I would have a fear of tigers, that I would try to lower the odds.

- Peter Benchley (author of Jaws)

Sharks are fish, big fish that are apex predators; ${ }^{1}$ yet, people and smaller fish still swim in the sea. "As the most powerful type of nongovernmental organization in the United States today and as the most dynamic form of organization in the world, the large corporation has enormous potential to affect communities for better or for worse." ${ }^{2}$ What does this mean for small communities when a large company comes to town? The common dialogue when a large company comes to a small town involves a cost benefit analysis regarding their presence. ${ }^{3}$ The introduction of a big superstore or big company headquarters implicates questions regarding: the impact of having the business as a community member (a neighbor, so to speak); the effect on local people (merchants, employees, children, etc.); the repercussions for local businesses, the changes to local law, rules, and regulations; the influence on the use of local resources (including environmental); managing allocation of funding; and the list continues. "Big box stores can be a blessing in that they often act as an anchor for further commercial development. However, some planners also criticize them for diminishing the unique feel of small towns." ${ }^{5}$

1. Sharks' Role in the Oceans, SHARKSAVERS, http://www.sharksavers.org/en /education/the-value-of-sharks/sharks-role-in-the-ocean (last visited May 28, 2016).

2. Stephen Halebsky, Small Towns and Big Business: Challenging WAL-MART SUPERSTORES 4-5 (2009).

3. Id. at 4 .

4. Id.

5. Meg White, Small Town, Big Ideas, Realtor Mag., Apr. 2013, http:// realtormag.realtor.org/news-and-commentary/feature/article/2013/04/small -towns-big-ideas (providing guidance to commercial real estate practitioners).

In revitalizing a commercial corridor such as Ogden Avenue, which stretches from the Goose Island neighborhood of Chicago into the exurbia of the city's outer metro area, a one-size-fits-all approach just won't cut it. By the time Ogden transforms into Route 34 in Oswego, [Illinois], the corridor is much more oriented to big-box stores and automobile traffic. The challenge for Rod Zenner, Oswego's community development director, is to attract high-profile retail while 
These considerations are all important, and as meaningful aspects of local business governance decisions, this article addresses the issues.

One argument against large companies coming to town identifies the infiltration of that company into community living as problematic. "While some accept this state of affairs as simply the nature of modern society, others object to what they perceive as a process of corporate colonization that is occurring without their input or approval." ${ }^{7}$ Further, large companies, particularly the large retailers, carry the label of driving out local competition in these small communities. ${ }^{8}$ Despite this perspective, local officials in some small communities may actually campaign to bring the large companies to town. ${ }^{9}$ Benefits include more jobs, better prices, and more purchasing options in the case of retailers. "It is important to note that the benefits of big box retailing, and the reasons they continue to be [developed], is that they offer low prices and 'great conveniences for . . . an increasingly time-deprived society." ${ }^{10}$ So often local governments and private-sector decision makers do not factor in the benefits of establishing a development plan to

still maintaining the character of the community. To accomplish this goal, Zenner works to create "unifying architecture" for strip mall developments with names like "Prairie Market" and "Oswego Commons."

Id.

6. HALEBSKY, supra note 2 , at 4.

It is not unusual for local independent businesses to be perceived as failing to operate in the best interest of the community. In fact, the case studies in this book reveal that many small retailers are rather unpopular with some of their fellow townspeople, who accuse them of charging high prices, stocking out-of-style merchandise, providing shoddy service, hiring only their relatives and friends, and having limited hours.

Id. at 5 .

7. Id. at 4.

8. Kenneth E. Stone, Impact of the Wal-Mart Phenomenon on Rural Communities, in Increasing Understanding of Public Problems and Policies 189, 199 (Farm Foundation 1997), http://ageconsearch.umn.edu/bitstream/17713 /1/ar970189.pdf ("Studies in Iowa have shown that some towns below 5000 population have lost nearly half their retail trade in the last [thirteen] years.").

9. Id. "Representatives from the outlying smaller towns have the least representation in this decision making process and, consequently, they suffer the greatest losses." Id.

10. Big Box Retail, New Rochelle Studio, http://www.columbia.edu/itc /architecture/bass/newrochelle/extra/big_box.html (last visited May 28, 2016). 
respond to economic, social, and environmental concerns. ${ }^{11}$ Acting individually or as a united guild in this planning process improves outcomes. This article addresses the benefits of stakeholders making the governance decision to work together, and proactively recognizing the importance of the employees and consumers working in concert. Similarly, local government actors may have a narrowed vision, focusing only on concerns of appearance, aesthetics, and generating taxes. ${ }^{12}$ Both local governments and private-sector decision makers have ignored the benefit of developing a retail plan and specific proactive policies. ${ }^{13}$ When these types of development plans are analyzed, the analysis usually does not include reference to more than the power of the community at large or the individual local businesses. ${ }^{14}$

This article will first briefly set forth the common characteristics of small communities and the aspects that draw business. ${ }^{15}$ Next, the article will provide information about big businesses and the impacts they have on small communities, with an emphasis on the Wal-Mart effect. ${ }^{16}$ This article provides recommendations for governance decisions from the perspective of the small business owner in the small community, which should be considered tools for the small business in its governance-decision tackle box. ${ }^{17}$ When a small business faces the potential (or already existing) entrance of a big fish into the small sea, this article offers considerations for the business' management and board to consider when making decisions related to allocation of resources. $^{18}$ This article emphasizes that for a more beneficial transition, particularly for local businesses, decision makers should focus efforts on collaborating their planning with other local businesses and the local government. ${ }^{19}$

11. Bruce H. Ozuduru \& Jean-Michel Guldmann, Retail Location and Urban Resilience: Towards a New Framework for Retail Policy, 6 S.A.P.I.EN.S. 1, 2 (2013).

12. Id.

13. Id.

14. See infra Section III.A.

15. See infra Section II.A.

16. See infra Sections II.B-.C.

17. See infra Section III.A.

18. See infra Section III.A.3.

19. Ozuduru \& Guldmann, supra note 11, at 2 (indicating that through "collaborat[ion] with public sector decision-makers . . . sustainable urban development will be enhanced”); see infra Section III.A.1. 
Moreover, this article emphasizes that one key tool that has been ignored, and should be an integral part of management's and the board's informed decision making, is the power of the employees who will work in the large company and the consumers who will shop there. ${ }^{20}$ To this end, this article will set forth the relevant details of the Market Basket Supermarket events from summer 2013, which most notably demonstrate the power flexed by the non-unionized employees and its customers. ${ }^{21}$ In light of the strength of the impact of the actions of the other stakeholders, including employees, customers, and the community, this article will conclude with an examination of the inter-related interests of these various stakeholder actions in a small community. ${ }^{22}$

\section{SMALl TOWNS AND BIG BUSINESS}

This section examines the qualities of small communities, and explores why big companies, the big fish, may swim in the small sea of a small community. ${ }^{23}$ The section will examine the actual impact that some big companies have brought to these communities-for better or worse.

\section{A. Shopping in Small Towns and Rural Communities}

Historians attribute the rise of urban centers in the United States to the infiltration of the railroad. ${ }^{24}$ With the start of the nineteenth century, the draw of urban centers fueled the rise of big business. ${ }^{25}$ During the early 1900 s, technology became the fuel to spur on big business. ${ }^{26}$ Retail provides shoppers access to an increasing variety of goods and services, offers jobs to locals, generates local government taxes, encourages a certain type of neighborhood development, and helps to create "a sense of urban life vitality." ${ }^{, 7}$

In the 1950s and 1960s, shopping malls began popping up in the larger centers of trade and changed the American approach to

\footnotetext{
20. See infra Section III.B.

21. See infra Section III.B.

22. See infra Part IV.

23. See infra Section II.A.

24. Alfred D. Chandler, Jr., The Beginnings of "Big Business" in American Industry, 33 Bus. Hist. Rev. 1, 2 (1959).

25. Id. at 5-6.

26. Id. at 2 .

27. Ozuduru \& Guldmann, supra note 11, at 2.
} 
shopping. ${ }^{28}$ Rural residents found malls attractive for the wide selections, accessibility, parking affordability and availability, comfortable climate, and longer hours of operation. ${ }^{29}$ As major forces in the determination of human activity, residential living and retail shopping experiences are the first activities to splinter off and move away from the city center. ${ }^{30}$ Researchers have attributed the sometimes irreversible demise of the community "downtown" to the growth of shopping malls. ${ }^{31}$ Shopping malls drew the shoppers from downtown to the mall, referred to as an "adjustment of traditional city-center retailers." ${ }^{32}$ The impact of shopping malls continues today. It is, however, varied and includes the degradation of the mall to complete inoperability, which plays a key part in reigniting the interest in and success of the downtown. ${ }^{33}$

The emphasis on shopping malls shifted in the late 1960s as discount department stores started to appear. "Discernible patterns of integration, combination, diversification, and administration influenced and were influenced by the rise of huge companies and oligopolistic industries. Price competition yielded to other weapons, and the economy adjusted to make room for the young giants in its midst." ${ }^{35}$ Now, when big businesses come to town, the impact shows most frequently in retail, restaurants, and lodging. ${ }^{36}$ Drawn to small towns, for instance, Wal-Mart, the world's largest retailer, made its headquarters in Bentonville, Arkansas. ${ }^{37}$

28. Stone, supra note 8, at 189.

29. Id.

30. Ozuduru \& Guldmann, supra note 11, at 2.

31. Stone, supra note 8, at 189.

32. Ozuduru \& Guldmann, supra note 11, at abstract.

33. Id. at 1 ("At the same time, the number of dead malls has been increasing in developed and developing countries, and in particular in the U.S., showing that large-scale shopping venues also need strategies for adaptation and change.").

34. Stone, supra note 8, at 189-90. Actually, Target, K-Mart, and Wal-Mart all started in 1962. Id.

These were not the first discount department stores, but they turned out to be the largest chains. The three companies expanded in completely different ways, however. K Mart initially located stores in relatively large communities and spread rapidly across the United States and Canada and within six or eight years had become a truly national chain.

Id. (citing Discount of the Decade, Discount STORE News (Dec. 1989)).

35. Chandler, supra note 24, at 1 .

36. See HALEBSKY, supra note 2 , at 4.

37. Small Towns with the Biggest Business, 24/7 WALL ST. (Sept. 27, 2012, 
Bentonville is a small town with a population around 35,000 people. $^{38}$

A shift happened, yet again, in the 1980s with the increasing rate of expansion of the discount department stores and the addition of a new type of store, referred to as a "category killer." 39 The category killer is a store that specializes in providing a thorough selection of items and services related to a narrow retail category. ${ }^{40}$ Rapidly, category killers dominated the marketplace and, as the name suggests, "killed off" smaller, similarly categorized businesses. ${ }^{41}$ Early examples of category killer stores that followed this path are Toys“R”Us and Home Depot. ${ }^{42}$

When the members of a community would like a big box store, chain store or restaurant, or category killer to enter the community, no matter how prepared the community thinks it has become, the members of the community should consider that they still do not know exactly what they have invited or what will happen as a result. ${ }^{43}$ Research has shown that when discount mass merchandisers maintain a store in a community for "an extended period of time," shoppers will tend to shop at these stores, causing a loss of sales at competing stores. ${ }^{44}$ For these reasons and others, small communities often experience efforts to keep big companies, namely superstores, out.

\section{B. What Is It About the Big Fish and Little Sea?}

Why small towns? Generally, small towns offer comfort. ${ }^{45}$ Often, they draw people for quality of life and a sense of belonging

3:22 PM) [hereinafter Small Towns], http://247wallst.com/special-report/2012/09 $/ 27 /$ small-towns-with-the-biggest-businesses/ ("Walmart is the exception, however. The majority of the 500 largest publicly-traded companies in the U.S. are concentrated in the biggest cities. More than one in five are located in one of only nine major U.S. cities, with the majority based in New York, Houston and Atlanta.").

38. Id.

39. Stone, supra note 8 , at 190 .

40. Id.

41. Id.

42. Id.

43. See White, supra note 5 .

44. Stone, supra note 8, at 197-98.

45. See generally Theresa Forsman, Small Towns, Big Successes, BloOMBERG Bus. (July 18, 2001), http://www.bloomberg.com/bw/stories/2001-07-18/small-towns -big-successes. 
to a community. ${ }^{46}$ Traffic and crime are generally low. They may be picturesque and offer stimulating recreational activities-the beach, mountains, and festivals-that draw visitors at certain times of the year. A business may launch in a smaller community to gain the advantage of drawing from customers in a region broader than just the community in which the company has opened. ${ }^{47}$ Similarly, the chances are high that the new business offers a product or service that is not already offered in the small community. ${ }^{48}$ Small communities offer a good starting and operational base for big companies, and the interest in basing the business in the small communities frequently comes from the preferences of founders or owners for their own small communities.

On the other hand, communities with smaller populations experience more challenges providing choices and, sometimes, even an option of goods and services. ${ }^{50}$ Similarly, the impact of economic difficulties can be more widespread and deeper in small communities. ${ }^{51}$

For a company's headquarters, a major city has many attractions, including being in the middle of commercial enterprises and having access to information, services, and products. $^{52}$ Cities offer a larger and more diverse potential

46. See Billie Jo Jannen, How to Bring Business to Small Town, Hous. Chron., http://smallbusiness.chron.com/bring-business-small-towns-20765.html (last visited May 28, 2016).

47. See Charley Moore, Why Small Towns Are Boons for Small Business, InC.COM (Jan. 9, 2014), http://www.inc.com/charley-moore/why-small-towns-are-boons-for -small-business.html.

48. Id.

49. Les O'Dell, Business Owners Making It Big in a Small Town Environment, S. Bus. J. (Mar. 5, 2013) ("For owners of many rural manufacturers, location is simply a matter of starting a business where they live or continuing business where it started, but other benefits often become apparent."), http://thesouthern.com /business/local/business-owners-making-it-big-in-small-town-environment/article _bb72ebda-85dd-11e2-b6c0-0019bb2963f4.html.

50. Jannen, supra note 46.

51. Id. ("[E]ven a smattering of home repossessions and business failures affect nearly everyone.").

52. Small Towns, supra note 37.

These [ten] towns are located in five separate states, on both the east and the west coast. The companies operate in a host of industries, including credit card processing like MasterCard, food and beverage companies like PepsiCo, and real estate financing companies like Freddie Mac. One thing these towns have in common is that each is located near a major city. Three of them-Lake Forest, Glenview, and 
employee pool. ${ }^{53}$ Smaller communities may be attractive because of a seasonal recreational activity (like skiing or surfing) or because of the beautiful landscape. ${ }^{54}$ Often, however, these small community assets are not attractive to big businesses since those assets do not tend to attract year-round populations. ${ }^{55}$ Big businesses want "a year-round, sustaining population ... [that is] younger, with families. ${ }^{, 56}$ Consequently, when government administrators seek to revitalize a community, emphasizing certain assets over others may or may not draw big business, and it may not necessarily be abundantly clear. ${ }^{57}$

\section{Does This Big Fish Really Stink? The Wal-Mart Effect and Other Effects}

It is hard to say. "Many people are concerned not only about local autonomy ... but also about economic well-being, community character, and local quality of life." ${ }^{, 58}$ Frequently, local merchants drive the battle against entry by the big stores. ${ }^{59}$ To understand this dynamic, it is helpful to take a look at the impact of real life entrance of a big fish in a small sea-Wal-Mart and other big merchandisers-to understand the issues faced by the small

\footnotetext{
Deerfield-are suburbs of Chicago. Two small cities, McClean and Falls Church, [Virginia], are suburbs of D.C. These suburbs can provide a good location for corporations, drawing from the benefits of being close to a major city, as well as the positives of being in a suburb. community's assets, sometimes the very elements that make a place attractive can be a barrier to development. David Milder-president and founder of commercial consulting firm DANTH Inc. as well as Dane's partner in the effort to revitalize Sherwood-noted that the town's traffic was both a boon and also a factor contributing to the decline of the downtown area.

Id.

58. HALEBSKY, supra note 2, at 4.

59. Stone, supra note 8 , at 199. "However, in more and more cases, people who are genuinely concerned about preservation of historic sites and natural resources, organize the resistance." Id. at 15.
} 
communities. $^{60}$ A definition of "big box" retail that helps to understand the concept of the big fish includes the following characterizations:

[They t]ypically occupy more than 50,000 square feet, with typical ranges between 90,000 [and] 200,000 [square feet, d] erive their profits from high sales volumes rather than price mark up[, l]arge windowless, rectangular single-story buildings [, s] tandardized facades [, r] eliance on auto-borne shoppers[, a]cres of parking[, n]o-frills site development that eschews any community or pedestrian amenities. [They s]eem to be everywhere and unique to no place, be it a rural town or urban neighborhood[, v]arying market niches; categories include discount departmetn [sic] stores, category killers and warehouse clubs. $^{61}$

While all "big box" retailers are big fish companies for the purposes of this article, not all big fish companies are "big box" retailers.

Wal-Mart fits the definition of a big fish. Wal-Mart is headquartered in a small town, and it initially located its stores in small southern towns. ${ }^{62}$ Small rural towns provided opportunities for Wal-Mart to keep its operating expenses low, with an emphasis on payroll and rent. ${ }^{63}$ As a discount mega-store, Wal-Mart

60. Small Towns, supra note 37.

$[\mathrm{T}]$ here are several small towns, cities, and suburbs that are home to at least two of [the] country's largest companies. In two cases, six fortune 500 companies are headquartered in these cities. Based on a review of the headquarters of the largest companies, [24/7 Wall Street] identified the [ten] small with the biggest businesses.

$I d$.

61. Big Box Retail, supra note 10.

62. Stone, supra note 8, at 190.

As can be seen, the average growth in general merchandise sales for the Wal-Mart towns was spectacular for the first few years, averaging approximately [fifty] percent growth (most of which was obviously Wal-Mart's). However, after about five years, sales began declining and after [ten] years were [twenty-five] percent higher than before the Wal-Mart store opened. It is believed that this decline in sales happened because Wal-Mart placed its own stores too close together, causing a predatory effect. At the same time, the build-up of large stores in bigger towns and cities captured some sales from even the Wal-Mart towns.

Id. at 191 .

63. Vijay Govindarajan \& Anil K. Gupta, Taking Wal-Mart Global: Lessons from 
experienced quick retail dominance in these communities. ${ }^{64}$ Those in favor of bringing Wal-Mart to town credit the move with increased tax revenues and jobs, more product choices, and a decrease in product prices. ${ }^{65}$ Those against bringing Wal-Mart to town attribute the move with increased traffic, lowered wages, nonunionized jobs, and homogenization of the community. ${ }^{66}$ In those communities where Wal-Mart had not previously opened a store, the survivability of other general merchandise stores declined immediately after Wal-Mart moved in. ${ }^{67}$ Similar to Wal-Mart's approach, another big fish, Target, selectively targets markets for retail dominance. ${ }^{68}$

Retailing's Giant, Strategy + Bus. (June 19, 2002), http:// www.strategy-business.com/article/13866?gko=17e9c. "Competitors, such as Kmart, which were focused on large towns with populations of more than 50,000, ignored Wal-Mart. This built effective entry barriers as it became highly uneconomical for competitors to enter regions Wal-Mart had already saturated." Id. (citing Rob Lynch, Case Study: How Wal-Mart Keeps Its Competitive Edge (1996)). For a global example, when it entered Brazil, Wal-Mart "chose to focus on areas where it could differentiate itself: customer service, targeted at neutralizing [France-based multinational retailer] Carrefour, and merchandise mix, targeted at overwhelming smaller local competitors." Id.

64. Stone, supra note 8, at 189-90. "Wal-Mart's founder, Sam Walton, did not want to outrun his logistical support; namely, his distribution centers. Consequently, Wal-Mart progressed methodically across the United States, always building stores within a day's drive of its distribution centers, and taking over [thirty] years to become a fully national chain." Id. at 190 .

65. Preston W. Mitchell et al., When Wal-Mart Doesn't Come to Town: Competitive Responses of Established Retail Merchants in Edenton, North Carolina, 46 GEOGRAPHICAL BuLl. 15, 17 (2004), http://www.gammathetaupsilon.org/the-geographical -bulletin/2000s/volume46-1/article2.pdf.

66. Id.

67. Stone, supra note 8, at 191.

The study looked at [thirty-four] towns in Iowa that had Wal-Mart stores for at least [ten] years. The retail performance of these towns was compared to [fifteen] towns of the same population group that did not have Wal-Mart stores. The population of these towns ranged from 5,000 to 40,000 persons.

$I d$. at 190-91. "Wal-Mart even scares businesses that aren't direct competitors, at least not yet. Banks, for instance, lobbied Congress hard to keep Wal-Mart from becoming an industrial loan corporation, which, in effect, would have allowed it to offer banking services." Terry J. Fitzgerald \& Ronald A. Wirtz, The Wal-Mart Effect: Poison or Antidote for Local Communities?, FED. REs. BANK MinNEAPOLIS (Jan. 1, 2008), https://www.minneapolisfed.org/publications/fedgazette/the-walmart-effect -poison-or-antidote-for-local-communities.

68. Stone, supra note 8, at 190. 
Due to the competing claims of Wal-Mart's impact on small communities, the Minneapolis Fedgazette conducted a study to determine the economic impact Wal-Mart stores had on communities in the Ninth Federal Reserve District by looking at forty small counties in which a Wal-Mart store opened between 1986 and $2003 .^{69}$ The study compared these forty counties with forty-nine counties of similar size without a Wal-Mart store, analyzing 1985 to 2005 job numbers, number of firms, population, incomes, and poverty levels. ${ }^{70}$ Fedgazette found that contrary to feared problems that communities hope to avoid associated with Wal-Mart coming to town, such as destruction of local business and jobs, the study found that local communities actually experienced growth of local business, increased employment, and stronger earnings. "The research does suggest that retail earnings per job fell in virtually all counties studied. But they actually fell by less in Wal-Mart counties." ${ }^{, 72}$

Among other things, the Fedgazette study determined that over two decades personal income grew almost identically in Wal-Mart and non-Wal-Mart communities. ${ }^{73}$ The researchers determined that the existence of Wal-Mart had little influence on income growth. ${ }^{74}$ The study also showed that in the Ninth District between 1985 and 1997, both non-Wal-Mart communities and Wal-Mart communities experienced similar declines in the number of general merchandise stores. ${ }^{75}$ With regard to employment, however, the Fedgazette study showed that median employment growth was higher in Wal-Mart communities than non-Wal-Mart communities. ${ }^{76}$

69. Fitzgerald \& Wirtz, supra note 67. "Conventional wisdom suggests that Wal-Mart's economic influence is significant and obvious. If that's indeed the case, then we should see palpable change in measures commonly used as proxies for community health—things like jobs, firms, income, population and poverty." Id.

70. Id.

71. Id.

72. $I d$.

73. Id. (indicating that this was in both median and aggregate).

74. Id.

75. Id.

76. Id. (sharing that the difference between communities with or without Wal-Mart shrinks for aggregate employment figures). "This is due in part to five booming non-Wal-Mart counties (out of [forty-nine]) that saw employment growth exceed 100 percent over this period; all but one border a metro county." Id.

While many efforts to pinpoint the locations of high-growth companies study only high-population metropolitan regions, the NCOE took another tack and combed through census data that lists annual 
Further, the growth in taxable sales matched or was higher in Wal-Mart communities versus non-Wal-Mart communities. ${ }^{77}$ The Fedgazette researchers also determined that in Wal-Mart towns, poverty rates decreased less than in the surrounding communities. ${ }^{78}$ Given that the results of this study showed plusses and minuses, and with small effects both ways, some have said the effects may cancel each other out. ${ }^{79}$ Others have read the results as showing most strongly that when Wal-Mart comes to town, there is no prediction of the effect on the community's economic success. ${ }^{80}$ In any case, the impacts are important for business governance decision making.

In a study conducted looking at thirty-four Iowa towns that had Wal-Mart stores for ten years or more, the researchers compared the information to fifteen towns that did not have Wal-Mart stores. ${ }^{81}$ The population of all of these towns was between 5000 and 40,000 people. $^{82}$ The Iowa study showed the correlative impacts of Wal-Mart on the communities in which the stores are located and the surrounding communities. ${ }^{83}$ In Wal-Mart towns, by the second year after the opening of a Wal-Mart store, total sales increased by

employment at every company in every county in the country. It was specifically looking for companies where employment grew by $15 \%$ or more per year between 1992 and 1997, or where the workforces at least doubled over the same period. Nationwide, fewer than $5 \%$ of companies meet that criteria.

Forsman, supra note 45.

77. Id.

78. Id. ("Despite positive associations with some basic economic measures, Wal-Mart counties saw their poverty rates drop much less than non-Wal-Mart counties, both in median and average terms . . . Overall, counties with and without Wal-Mart had similar growth in population and income per person.”).

79. Id.

It should be emphasized that there are big differences in population, income and employment growth rates among the counties studied. Some counties with a Wal-Mart had strong growth, and other Wal-Mart counties had slow growth. Similarly, there were fast and slow growers among non-Wal-Mart counties. The point here is that Wal-Mart's presence explains little of this disparity pattern. Still, some notable outcomes did show through in the study.

Id.

80. Id.

81. Stone, supra note 8, at 192-93.

82. Id. at $190-91$.

83. Id. 
$6 \%$ and maintained that status through year seven. ${ }^{84}$ Beginning in the eighth year, however, a decline in sales led to sales figures $10 \%$ below pre-Wal-Mart numbers by year ten. ${ }^{85}$ The researchers concluded that this decline was most likely due to the impact of several mass merchandiser stores opening in the region that took shoppers that previously made the trip to the Wal-Mart town. ${ }^{86}$ The Iowa study showed sales at eating and drinking establishments in Wal-Mart towns increased $3 \%$ to $7 \%$ compared to the statewide average. In contrast, the non-Wal-Mart towns experienced an immediate decline that, after ten years, left sales at $9 \%$ under the statewide average. ${ }^{87}$ The researchers determined that these results showed that people actually leave non-Wal-Mart towns to go shop at Wal-Mart (referred to as "destination retail") and, therefore, frequent the establishments in the Wal-Mart towns while shopping at Wal-Mart. ${ }^{88}$ Thus, the researchers saw a positive effect for eating and drinking establishments in Wal-Mart towns due to the store's power to draw people from outside that small community.

The Iowa study also showed impacts in specific retail categories. One such finding determined that stores selling home furnishings experienced only a slight decline when Wal-Mart came to town, versus non-Wal-Mart towns where sales ended up declining by $31 \%$ after ten years. ${ }^{89}$ A conclusion drawn from this finding was that when people came to shop at Wal-Mart, they took the opportunity to shop for home furnishings in the same

84. Id. at 196 .

85. Id.

86. Id. at 196-97; see also Fitzgerald \& Wirtz, supra note 67 ("Sales tax data offer another window on Wal-Mart's economic effect. Wal-Mart likely attracts shoppers from neighboring counties, and wider selection might also induce more frequent shopping. But a new store might also squeeze out other local retailers.”).

87. Stone, supra note 8, at 196.

88. Id:; see also Harms of Big Box Retail, GoODJobsFirst.ORG, http:// www.goodjobsfirst.org/smart-growth-working-families/harms-big-box-retail (last visited May 30, 2016)

A few retailers-Cabela's and Bass Pro come to mind-have mastered the ultimate illusion of "destination retail," enticing shoppers from great distances. In the case of Cabela's, the bait is pseudo-outdoors settings such as its Conservation Mountain store centerpieces with wildgame taxidermy. In some cases, these attractions are legally structured as a condominium within the store and owned by the local government (as a pseudo-museum), and are therefore exempt from property taxes.

Id.

89. Stone, supra note 8, at 192-96. 
community. ${ }^{90}$ Contrarily, the study found that building materials stores in Wal-Mart and non-Wal-Mart communities for the first few years suffered immediate and mediocre sale declines after a Wal-Mart store opened. ${ }^{91}$ According to the Iowa study, after seven years, building material sales experienced a $20 \%$ decline. $^{92}$ Interestingly, sales figures started improving around the eighth year after a store opened. ${ }^{93}$ Ten years after the opening, sales figures showed a $4 \%$ improvement over sales from before the Wal-Mart store opened. ${ }^{94}$

Looking at apparel sales, the Iowa study found that after ten years, sales dropped for apparel stores in Wal-Mart towns to 28\% below the sales figures from the time before the store opened. ${ }^{95}$ In non-Wal-Mart towns, the apparel stores' sales numbers experienced the same decline. ${ }^{96}$ The study determined that low-end apparel stores that competed directly with Wal-Mart suffered the losses. ${ }^{97}$ Specialty stores also experienced a decline in sales-10\% in Wal-Mart towns after three years, and, after experiencing a brief improvement, declined further to $17 \%$ by the end of the tenth year. ${ }^{98}$ In non-Wal-Mart towns, the sales at specialty stores declined to $29 \%$ by the end of the seventh year. ${ }^{99}$ The researchers determined that these results evidenced that the stores selling the same products as Wal-Mart lost sales. ${ }^{100}$

The Iowa study also showed that communities with a population of 5000 people or less were the most affected by discount mass merchandisers. ${ }^{101}$ If the mass merchandiser moves

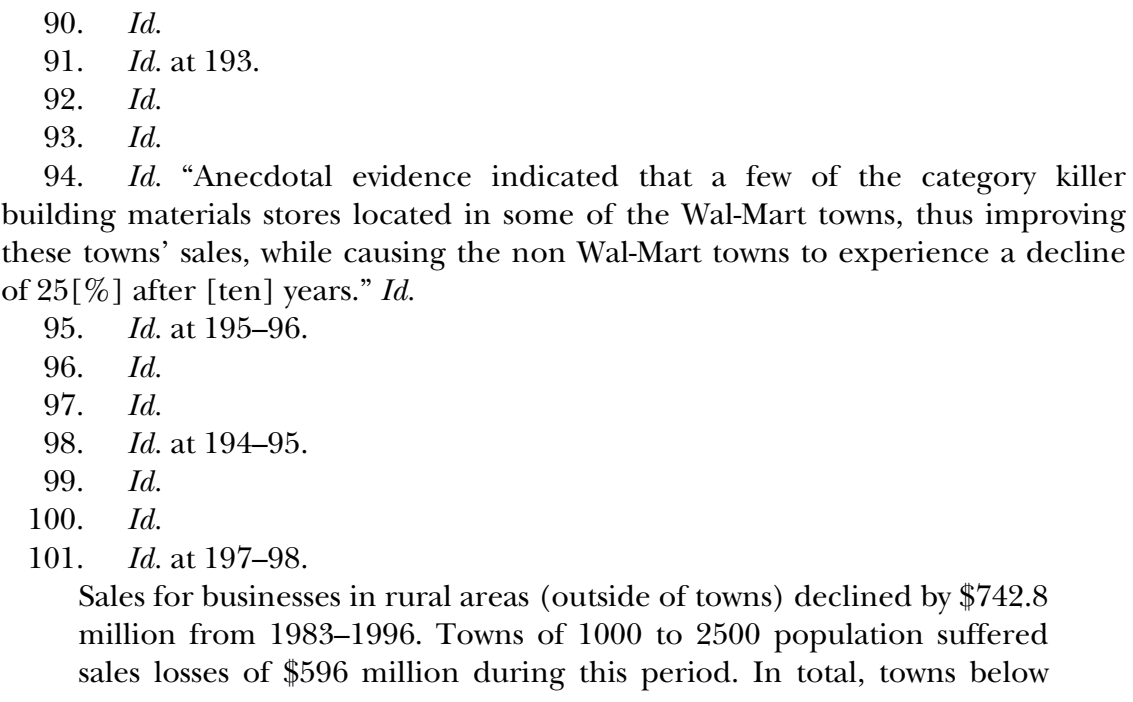


nearby, the community with a population of 5000 people or less did not have enough retail establishments to engage customers to stay in the small community at home. ${ }^{102}$

The consulting firm Civic Economics conducted studies that showed that retail chains, as compared to local businesses, generally pay lower wages and provide fewer benefits. ${ }^{103}$ The firm's studies have shown that retail chains provide fewer positive impacts on the economics of local communities-they buy less, bank locally less, and provide less support of community events. ${ }^{104}$ A survey and corresponding analysis conducted by the Institute for Local SelfReliance (ILSR) showed that local businesses experience challenges in their efforts to secure financing necessary to grow the business in comparison to the experience of big business. ${ }^{105}$ The ILSR research revealed that since 2000, loans from banks to big businesses grew 36\%, whereas loans to small businesses fell $14 \%$, and "micro" businesses loans (loans under \$100,000) fell 33\%. ${ }^{106}$ Lack of demand is not the cause of the falling number of loans. ${ }^{107}$ "Startups, businesses with fewer than [twenty] employees, and enterprises owned by minorities and women are having an especially difficult time." ${ }^{108}$ These local and minority businesses are losing market share due to lack of capital. ${ }^{109}$ ILSR points to broader problems for this disparity, singling out local businesses as "a primary source of net new job creation, [which] contribute[s] to

5000 population, plus the rural businesses, lost retail sales of $\$ 2.46$ billion during this [thirteen]-year period.

Id.

102. Id.

103. See Matt Cunningham \& Dan Houston, The Civic Economics of Retail, Loc. FIRST SPRINGFIELD, http://localfirstspringfield.com/Resources/Documents/The \%20Civic\%20Economics\%20of\%20Retail\%5B1\%5D.pdf (last visited May 30, 2016); see also Harms of Big Box Retail, supra note 88.

104. See Harms of Big Box Retail, supra note 88. See generally Cunningham \& Houston, supra note 103.

105. Stacy Mitchell, Understanding the Small Business Credit Crunch, InST. Loc. SELF-RELIANCE (Apr. 16, 2014), https://ilsr.org/understanding-small-businesscredit-crunch/.

106. Id. ("One consequence of this credit shortage is that many small businesses are either not adequately capitalized or have been forced to rely on high-cost alternatives, such as credit cards. Both scenarios make them more vulnerable to failing.").

107. Id.

108. Id.

109. Id. 
higher median household incomes, and increase[d] social capital." 110

These studies offer insight into the impact of the big fish moving into the small sea. Without access to the types of information offered by these studies, local businesses facing the entrance of a big fish into the small sea will not be able make informed decisions. Further, no study exists that offers insight into the impact that locally employed employees at the new big fish or big fish consumers can have on the big fish's behavior.

\section{RECOMMENDATIONS FOR THE SMALL FISH AND SMALL SEA}

What does this often discussed and analyzed dynamic mean for business transactions in small communities? This article examines certain recommendations in light of the above described big fishsmall sea characteristics. ${ }^{111}$ Putting a new spin on the old story of the Big Fish in the Small Sea, the article then examines this dynamic in light of the implications from the events that occurred during the summer of 2013 with Market Basket supermarkets. ${ }^{112}$

\section{A. General Recommendations: Some Tools in the Tackle Box}

The impact of small companies in small communities rarely amounts to the impact made by big companies. ${ }^{113}$ The big fish have the large size and scale that leads to such business having a significant impact on the community. ${ }^{114}$ This big fish may be the community's "largest local employer, the single biggest local taxpayer, the leading purchaser of locally produced products, or the dominant seller of everyday consumer goods." 115 The big fish may also, generally, have a bigger impact due to their ability to allocate more resources to manage public opinion, decisionmaking, and discourse over individual, small, local businesses. ${ }^{116}$ "Their ability to influence politicians through campaign finance is well known." 117

\footnotetext{
110. Id.

111. See infra Sections III.A-.B.

112. See infra Section III.B.

113. HALEBSKY, supra note 2, at 5 .

114. Id.

115. Id.

116. Id.

117. Id.
} 
As suggested earlier in this article, many communities wish to make efforts to keep big companies from opening up shop. ${ }^{118}$ The major participants in the process of bringing to town or repelling the big companies are the community governments and privatesector decision makers. ${ }^{119}$ These two actors often have competing interests and missions. ${ }^{120}$ The government attempts to enhance public welfare and strengthen community economics. ${ }^{121}$ Often community administrators look at community development from a short-term view, which emphasizes employment and increasing tax revenue. ${ }^{122}$ This short-term view tends to ignore the long-term implications that may result, such as the loss of local business. ${ }^{123}$ The loss of local business counters the short-term benefits by reducing employment and tax revenue. ${ }^{124}$ What should these administrators do? They should talk to people who run the local businesses to more fully understand how this part of the economy works, the identified problems, and suggested solutions. ${ }^{125}$

Private-sector participants, such as the local businesses, endeavor to maximize their profits. ${ }^{126}$ Sometimes the effort to repel big companies comes from people concerned about maintaining the historical and natural integrity of the community. ${ }^{127}$ More often, however, the greatest effort to repel comes from the people who own and run local stores who worry that the big company will trounce their little shop. ${ }^{128}$ When a big company comes to town, the situation may satisfy, if not please, both sides of the debate upon implementation of specific strategies, programs, and regulations. ${ }^{129}$

Together the private-sector and public administrators need to develop a plan to prop up the long-term economic viability of the

\footnotetext{
118. Stone, supra note 8 , at 199.

119. Ozuduru \& Guldmann, supra note 11, at 2. "Public officials are placed in difficult situations as they decide whether to recruit and/or approve the establishment of new mass merchandiser stores. There is a need for an educational program aimed at public officials, to help them make better decisions regarding this problem." Stone, supra note 8, at 199.

120. Ozuduru \& Guldmann, supra note 11, at 2.

121. Id.; Stone, supra note 8, at 199.

122. See Stone, supra note 8, at 199.

123. See id.

124. Id.

125. Forsman, supra note 45.

126. Ozuduru \& Guldmann, supra note 11, at 2.

127. Stone, supra note 8, at 199.

128. Id.

129. Ozuduru \& Guldmann, supra note 11, at 2.
} 
community. ${ }^{130}$ One argument is that instead of strategizing to keep out the big fish, a plan should be developed to use community resources to promote the community's economic development. ${ }^{131}$ If both private and public parties approach the entry of the big business with a positive attitude, more resources can be spent on the economic development plan-instead of thwarting. ${ }^{132}$ All strategic planners, like local administrators, however, should take care not to provide overly generous incentives to big fish that damage the small local businesses or put those local businesses at a disadvantage. ${ }^{133}$ Further, the incentives to the big fish, particularly regulatory, should not diminish the potential impact of the local employees that will work at the big fish and the consumers that will shop there.

This plan requires its creators to understand how the local and global economy works, and thereby identifies ways to use these forces to promote economic growth locally, including the creation of well-paying jobs. ${ }^{134}$

\section{Land Use Planning and Zoning}

Land use planning and zoning are two of the greatest tools a community has to give it the power to either thwart a big company

130. See Elena G. Irwin \& Jill Clark, Wall Street vs. Main Street: What Are the Benefits and Costs of Wal-Mart to Local Communities?, 21 CHOICES MAG. 117, 120 (2006), http://www.choicesmagazine.org/2006-2/grabbag/2006-2-14.htm.

131. Id. ("The critical question for these communities is on what terms should the big boxes be welcomed?"); Big Box Retail, supra note 10.

132. Stone, supra note 8, at 199. "In a free enterprise economy, all firms are free to compete." Kenneth E. Stone, Competing with the Discount Mass MERCHANDISERS 3, http://www.extension.iastate.edu/sites/www.extension.iastate .edu/files/harrison/CompetingWithMassMerchandisers11.pdf (last visited Mar. 9, 2016).

133. See Stone, supra note 8, at 199.

134. Irwin \& Clark, supra note 130, at 120.

A good example is Aurora, Nebraska. Community leaders in Aurora, a town of just over 4,000 people, decided to leverage their assets-local proactive leadership, dedicated community volunteers and an existing high-tech telecommunications company-to create their competitive advantage. In addition, they anticipated the potential labor needs and prior to recruitment instituted a training program for residents to work in this industry. Capitalizing on their technological infrastructure, available labor force and quality of life, Aurora officials were able to woo a couple of high-tech communications firms.

Id. (citation omitted). 
from entering the community or manage the impact. ${ }^{135}$ For example, if entry by the big company is inevitable, as a first step, a community may establish specific and required design rules and pedestrian-friendly guidelines. ${ }^{136}$ In this way, small, local companies would be well advised to become a part of this processrecognizing that preserving the community aesthetic will benefit the community and therefore their business, but may also impose obligations upon local, small companies.

A report authored by Chris Duerksen and Robert Blanchard for the American Planning Association titled Belling the Box: Planning for Large-Scale Retail Stores provides helpful information and recommendations on these first stage issues, such as architectural details, colors, relationship with neighboring communities, pedestrian access, parking, and other projects in the area. $^{137}$

The recommendations that Duerksen and Blanchard make in the report may be used as a guide for other communities. ${ }^{138}$ Examples include: prohibiting " uninterrupted length of any facade' in excess of 100 horizontal feet," 139 requiring small retail stores in a larger building have separate outside entrances and display windows, ${ }^{140}$ and fifty percent as the maximum percentage of off-street parking that may be provided in the area between the front of the main building and the street. ${ }^{141}$ Along this line, to preserve the aesthetic of a downtown neighborhood, design rules may be written to require an increased level of architectural detail and treatment to ensure the big company stores fit in better with their new surroundings. ${ }^{142}$ Since this is only the first step in

135. See Stacy Mitchell, Two Big-Box Decisions Show How Smart Planning Policies Protect Good Jobs, Inst. Loc. Self-Reliance (Apr. 1, 2014), https://ilsr.org/smart -planning-policies-protect-good-jobs-cities-vote-big-boxes ("Two recent decisions, in Massachusetts and Wisconsin, underscore why land use planning matters and how smart policies can strengthen the local economy and protect good jobs.").

136. See Big Box Retail, supra note 10.

137. Id.

138. Id.

139. Id. "Facades greater than 100 feet in length must incorporate recesses and projections along at least $20 \%$ of the length of the facade. Windows, awnings, and arcades must total at least $60 \%$ of the facade length abutting a public street." Id.

140. Id.

141. Id.

142. Id. 
managing a big company's entry into the community, the community must also prepare and take additional measures. ${ }^{143}$

\section{Legislating to Protect Employees}

Anticipatorily, the community may also take legislative measures to protect the people who will be employed in the community and protect their powerful voice. Once again, local, small companies should be involved in this process for various reasons, not the least of which is that the requirements may end up applying to them. For example, the state may pass a requirement that certain, or all, businesses must provide a minimum amount of employee benefits. ${ }^{144}$ This mandate responds to not only the ethical issue that the big company should not take advantage of the local employment pool and, therefore, provide reasonable compensation, but also that employees without adequate benefits could place an increased burden on the community's assistance programs. ${ }^{145}$ One counter-effect that must be kept in mind is that these requirements increase costs to employers and, therefore, may result in the employers employing fewer local people or charging increased prices for services or products. ${ }^{146}$

\section{Being Flexible and Efficient}

When facing the possible changes associated with having a big fish come to town, all community members involved in bringing the big fish to the little sea must be flexible and efficient. Initially, of course, the flexibility comes in when local stakeholders, such as community administrators and local businesses, work together. The small business that sees the possibility of a big fish coming to town should consider what small fish do in the sea when threatened by, say, a shark. Like a school of fish, a pod, or a shoal, there is safety in numbers.

\footnotetext{
143. Id.

144. Irwin \& Clark, supra note 130.

145. Id. However, Irwin and Clark acknowledge that "this conclusion depends critically on whether large retailers such as Wal-Mart are imposing an additional social burden by displacing retail jobs with better benefits [versus] lessening the social burden by providing health care benefits to otherwise unemployed workers." Id.

146. Id.
} 
Multiple local businesses benefit from forming a guild. ${ }^{147}$ Nellie Akalp, CEO of CorpNet.com, "describes this congregation of small businesses as 'a school of little fish [that] team up and swim as one big fish to avoid being eaten.' In other words, she says, small businesses are swimming in an ocean that's far more dangerous than ever before." 148

Consequently, a wise governance decision is for each small business to collaborate with other local retailers in an organized manner, such as creating a guild. Take, for example, the guild successfully formed in Edenton, North Carolina in response to a big box retailer. ${ }^{149}$ The Edenton guild implemented five primary accomplishments to benefit local merchants, which included: (1) building collaboration with businesses that were not in the downtown region; (2) refining the region of the market; (3) pooling revenue for advertising; (4) coordinating together for special discounts on sales; and (5) collaborating with previously existing chains. ${ }^{150}$ As members of the guild, or even without a guild, the local businesses may benefit from referring customers amongst each other. ${ }^{151}$ The guild in Edenton had great results when the local businesses pooled their advertising revenue. ${ }^{152}$ In this way, the guild members no longer paid for advertising individually and it gave the impression that Edenton offered a satisfying variety of goods and services. ${ }^{153}$ As a result, advertisements for local businesses quickly began appearing more frequently in the local newspapers and the ads were larger and more centrally located (i.e., not on the back of the paper). ${ }^{154}$ Some local businesses advertised for the first time. ${ }^{155}$ In fact, the guild invited the newspaper's advertising editor to attend the guild meetings. ${ }^{156}$ The guild took this approach

\footnotetext{
147. Mitchell et al., supra note 65 , at 18.

148. Moore, supra note 47.

149. Mitchell et al., supra note 65 , at 18

150. Id. ("The guild, which still operates today, devised several initiatives to increase the competitiveness, efficiency, and image of established retail merchants in Edenton.").

151. Moore, supra note 47.

152. Mitchell et al., supra note 65 , at 21.

153. Id.

154. Id.

155. Id.

156. Id.
} 
further and did similar advertising campaigns in newspapers of surrounding communities. ${ }^{157}$

Market research based on the specific community's size and economics can help determine the type of business a community can support. ${ }^{158}$ Local merchants should know the customer demographics to be able to offer the best merchandise choices and respond to other consumer preferences. ${ }^{159}$ These demographics will help management figure out whether the line of business and product or service choices fit in and have a greater potential of success in the community. ${ }^{160}$ The board or management of these local businesses may determine that an analysis of the local census data would offer the necessary key information, such as the ages, occupations, and incomes of the community members. ${ }^{161}$ Depending on the resources available to the small businesses and the decision by management to allocate available resources, another option is to hire marketing firms that will do this legwork

157. Id. (" $[\mathrm{S}]$ pecial inserts and full-page ads closer to the front of the paper in an attempt to capture the consumer's attention and give the impression of a large array of brand-name products available in Edenton.”).

158. White, supra note 5 (noting with reference to a specific town that could not "sustain apparel and furniture stores as easily as it [could] beauty shops, restaurants, and used-car dealerships"). "[O]ne major asset in attracting businesses to an area can be found in the real estate profession. [The author] encourages planners to find partners in real estate professionals who know their community well." Id. (citation omitted).

159. See Kenneth E. Stone, How local Merchants Can Compete 18 (1997), http://www2.econ.iastate.edu/faculty/stone/10yrstudy.pdf.

160. White, supra note 5 (providing guidance to commercial real estate practitioners).

Each of the country's 394 regions-labor-market areas, as defined by the census-has at least a handful of high-growth companies. . . . "What we say to community leaders is: You need to find out who these fast-growth companies are-typically a lot of these companies, because of their size, are below the radar screen of economic-development people."

Forsman, supra note 45.

161. STONE, supra note 159 , at 18 (indicating that this information can be found at most public libraries). Another way to get key information is with focus groups. "You may also want to conduct customer focus groups where diverse groups of customers under the direction of a third party moderator to discuss what they like and dislike about your business. These can be done by community colleges, other colleges and universities and by private consultants." Id. at 4 . 
and produce a report outlining the information in detail as it relates to the specific line of business. ${ }^{162}$

\section{B. Market Basket Implications}

The analysis of big fish coming to a small sea usually does not include reference to more than the power of the community at large or the individual local businesses. This article suggests that governance decision making should add the possibility of a more beneficial transition, particularly for local businesses, that should focus efforts and more resources on entering into collaboration for planning ${ }^{163}$-collaborations with other local businesses and the local community government. In order to have an effective plan, the participants need to understand the whole picture and conduct research. In this section, this article underscores that one key tool that has been ignored is the power of employees who will work in a large company and the consumers who will shop there. The impact of both previously ignored players can be best observed and argued by laying out the Market Basket supermarket saga from the summer of 2013. In this saga, the center stage is taken by the shocking, robust performance by non-unionized employees and customers. After laying out the saga, this article will explain the governance guidance to be taken away from the results.

Market Basket is a quintessential example of the family run business that started small in 1916 as a small fish in a small sea. ${ }^{164}$ The story of Market Basket, now a large grocery store chain headquartered on the east coast, provides an example of the impact of a large company in a small community. In particular, the Market Basket summer 2013 story uniquely demonstrates how a small community can engage to support one side in large business, the side that engages with the community. This power should wake some slumbering giants-big fish.

Market Basket is owned by Demoulas Super Markets, Inc. (DSM). ${ }^{165}$ The company usually locates Market Basket supermarkets

162. Id.

163. Ozuduru \& Guldmann, supra note 11 ("If private-sector decision makers become aware of the economic, social and environmental benefits of retail planning to increase economic resilience, and collaborate with public sector decision-makers, then sustainable urban development will be enhanced.").

164. History of Market Basket, MY DEMOULAS, http://www.mydemoulas.net / history (last visited May 30, 2016).

165. Id. In the past, some of the stores had the name Demoulas Market. Now, 
in shopping centers with other stores in local communities, and frequently Retail Management and Development, Inc., a commonly controlled company, owns the shopping center properties. ${ }^{166}$ Despite broiling family strife, the Market Basket chain has been successful. ${ }^{167}$ Since 2000, DSM has opened an average of four or five new supermarkets each year and has relocated some of its preexisting stores to new locations that are either newly constructed or newly renovated. ${ }^{168}$ Consumer Reports has even ranked DSM as the sixth best supermarket in the nation. ${ }^{16}$

The family business has been run by two sides of the Demoulas family, the "Mike side" and the "George side"-referring to the two sons of the founders. ${ }^{170}$ Since 1987, the two sides of the Demoulas family have become irrevocably antagonistic as a result of tax

however, all of the stores operate under the name Market Basket. Id. "[T] he last of which, [number] 6 in Salem, New Hampshire changed in spring 2010.” Id.

166. Id.

167. Id.

Only two stores in the chain's history-number 38, in Plaistow, New Hampshire (there were two in Plaistow, NH that were close to each other on Route 125. Now there's one) and number 11 in Andover, Massachusetts-have ever closed, although stores have closed in order to relocate to larger locations.

Id.

168. Id.

In April 2008, with the opening of then its newest store in Reading, MA (\#60) Market Basket has invested in opening [five] New locations, is in the process of building new stores to replace smaller, [sic] older, and outdated stores and it has also renovated and updated equipment in stores that where [sic] built within the last [fifteen] years. On June 10, 2009, Market Basket replaced its Chelsea, Massachusetts, store with a new building built on part of the DeMoulas-owned Mystic Mall. The New Bedford, Massachusetts (\#65) store had its grand opening on Wednesday, October 6, 2010. On December 12, 2010, next door to their previous store, the Burlington, Massachusetts (\#24) Market Basket opened their new store, [three] times the size of their previous store. The 108,000-square-foot . . . brand new Londonderry, New Hampshire (\#42) Market Basket celebrated its grand opening on June $5,2011$.

Id.

169. Paige Cooperstein, Consumer Reports Reveals the 10 Best Supermarkets in America, YAHOO Fin. (Mar. 31, 2014, 2:44 PM), http://finance.yahoo.com/news /consumer-reports-says-10-best-171113893.html; ylt

=AwrC1Cna08dWwxsAKj6TmY1Q;_ylu=X3oDMTEzc2p0NzZ1BGNvbG8DYmYxBHB vcwMyBHZ0aWQDVklEUFJEXzEEc2VjA3Nj.

170. History of Market Basket, supra note 164. 
irregularities filed by the Mike side for George's children. ${ }^{171}$ After a lengthy trial, a jury found that the Mike Demoulas side of the family had engaged in wrongdoing against the George side of the family. ${ }^{172}$ Despite these problems, DSM continued to grow. ${ }^{173}$

After the jury trial, and by order of the court, the George side of the family would hold a slight majority of shares in the company as compared to the Mike side. ${ }^{174}$ The family factions would also be assigned different classes of shares. ${ }^{175}$ The George family faction, embodied by George's son, Arthur S., received Class A shares. ${ }^{176}$ The Mike family faction, embodied by Mike's son, Arthur T. (Arthur S.'s cousin), received Class B shares. ${ }^{177}$

Additionally, the court ordered that the board of directors be reorganized to include seven directors. ${ }^{178}$ Each class of shares, Class A and Class B, would appoint two directors, either family members or nominees. ${ }^{179}$ Together, Class A and Class B would appoint three directors who are "disinterested, independent directors who meet the standards for independence as published by the New York Stock Exchange" (referred to as "A/B directors"). ${ }^{180}$ From 1999 to June 2013, a sub-group of the Class A shareholders, referred to as the "Rafaela group," voted consistent with the Class B shareholders. ${ }^{181}$ Consequently, the Class B shareholders controlled

171. Tara Myslinkski, Demoulas v. Demoulas SuperMarkets, Inc.: A Case Study in Business Ventures Going Bad, Bos. Bus. Divorce (July 11, 2012), http:/ /www.bostonbusinessdivorce.com/demoulas-v-demoulas-supermarkets-inc.

Prior to 1987, DSM had been run amicably by two sides of the Demoulas family. Id. In 1987, the company experienced a series of events that precipitated the demise of friendly affairs between the two sides. Id. The Massachusetts Department of Revenue, in 1987, caught an irregularity in a tax filing that was in the name of George Demoulas' oldest son. Id. Mike Demoulas had submitted the return. Id. Not surprisingly, George's side researched the cause of the irregularities. Id. The further they dug, the more they realized that things were not as they should be. Id.

172. Demoulas v. Demoulas, No. 2013-3171A, 2013 WL 5754104, at *1 (Mass. Super. Ct. Sept. 25, 2013).

173. Christopher Gren, LETTER: Market Basket: A Little History, WickED LOC. Plymouth (Aug. 21, 2014, 2:55 PM), http://plymouth.wickedlocal.com/article /20140821/News/140829821.

174. Demoulas, 2013 WL 5754104 , at $* 1$.

175. Id.

176. Id.

177. Id.

178. Id.

179. Id.

180. Id. (citing Demoulas v. Demoulas, 703 N.E.2d 1149 (Mass. 1998)).

181. Id. at $* 2$. 
the selection of the A/B directors, despite Class B constituting a slight minority of the shares. ${ }^{182}$ Frequently, therefore, Class B is referred to as the majority controlling block during the 1999 to 2013 time period. During this period, the board appointed Arthur T., a shareholder in the Class B group, as chief executive officer of DSM. ${ }^{183}$

The animosity between the family members had not stopped Market Basket from continuing to be a successful, large company with markets all over New England. ${ }^{184}$ While Arthur T. ran the company as CEO, Consumer Reports ranked DSM as the seventh supermarket in the nation. ${ }^{185}$ DSM, through the leadership of Arthur T., nurtured strong local ties. ${ }^{186}$ The company put together a much appreciated retirement compensation fund for employees, with 6500 employees included. ${ }^{187}$ In 2014, the fund was valued at over $\$ 552$ million, with a contribution of $\$ 43$ million in 2013 . " [ In $2012]$, the company recorded net income of $\$ 217$ million on $\$ 4$ billion in revenue." 189

Arthur T. did not underestimate the value of the DSM employees in each supermarket. Employees valued him for his personal nature. They would relate stories of how he visited stores and remembers peoples' names, birthdays, and family concerns. ${ }^{190}$

One of the issues at the heart of the controversy between the two sides of the family derives from Arthur T.'s decision to fund an employee profit-sharing plan. The Arthur S. side saw funds that could have gone to shareholders go into the profit sharing plan. As part of this other stakeholder emphasis, in November 2007 DSM decided to invest \$12.5 million in Federal Home Loan Mortgage Corporation. In May 2008, DSM invested an additional \$33.75

\footnotetext{
182. Id.

183. Id.

184. Casey Ross, Fight for Control of Market Basket Leads to New Lawsuit, Bos. GLOBE (Sept. 6, 2013), http://www.bostonglobe.com/business/2013/09/05 /fight-for-control-market-basket-leads-new-lawsuit/0dssKvYTKZnzgdtno371tL /story.html.

185. Gren, supra note 173.

186. Id.

187. Id.

188. Id.

189. Id.

190. Callum Borchers, Arthur T. Demoulas's Personal Touch Can Cut Both Ways, Bos. GLOBE (Aug. 22, 2014), http://www.bostonglobe.com/business /2014/08/21/arthur-demoulas-profile-personal-touch-that-can-cut-two-ways /IqkmJ1i7A4AFKpLenN8vBM/story.html.
} 
million in Federal National Mortgage Association. In August 2008, the trustees reported those investments to the board of directors. ${ }^{191}$ In January 2009, the board of directors voted five to two to make a restorative payment to the profit sharing plan of $\$ 46$ million to replace the money lost to Freddie Mac and Fannie Mae. ${ }^{192}$

The shareholders from the Arthur S. side of the family sued. ${ }^{193}$ The lawsuit dragged on for years. ${ }^{194}$ In June 2013, Judge Zobel authorized the plaintiffs to "seek full recovery of the $\$ 46$ million loss." ${ }^{195}$

In June 2013, this saga saw the Rafaela group switch its voting alignment to vote consistent with the Class A shareholders. That Rafaela group held just over $4 \%$ of the shares. ${ }^{196}$ Correspondingly, the power to control the determination of the Class A/B director slots changed to the Class A shareholders. ${ }^{197}$ The Class A shareholders continued to hold a slight majority of shares, and their vote filled the majority of directors' position on the board, including Arthur S. to the board. ${ }^{198}$ The shareholders voted by a

191. Jana Kasperkevic, A Timeline of the Market Basket Supermarket Family Feud, GUARDIAN (Aug. 14, 2014, 8:00 AM), http://www.theguardian.com/money/us -money-blog/2014/aug/14/timeline-market-basket-supermarket-arthur-family -feud.

192. Id.

193. Id.

194. Id.

195. Id.

196. Id.

197. Demoulas v. Demoulas, No. 2013-3171A, 2013 WL 5754104, at *2 (Mass. Super. Ct. Sept. 25, 2013).

198. Id.

In August of 2012, the A shareholders designated defendant Keith O. Cowan as one of their two directors. Cowan, according to all the evidence submitted, has had a long and distinguished career in business and law, including a history of earnings such that he would have no economic need for the fees his service as a director of DSM would bring. He had no prior relationship or acquaintance of any kind with DSM or anyone involved with it. Soon after he began his service, Cowan developed concerns about the company, which he expressed in a letter to the then board chair, dated October 18, 2012. Cowan's letter indicated his intention to propose to the board resolutions that would impose certain limits on management's authority to act without board approval; establish an approval process for related-party transactions; require specified planning and analysis before real estate investments; and replace the trustees of the company's profit sharing plan. Cowan also expressed concerns about management's views regarding capital structure, and proposed that the board discuss that topic at its next 
majority to fill the A/B director positions with Keith O. Cowan and two others chosen by Class A shareholders. ${ }^{199}$

Soon after the appointment of the new board of directors, the Mike side, led by Arthur S., started taking steps to depose Arthur T., including visiting top DSM executives unannounced at their homes. ${ }^{200}$ When the Market Basket employees learned that Arthur S. was taking steps to depose Arthur T., they began showing their support for their chief executive officer, Arthur T., including attending board meetings to rally for Arthur T. ${ }^{201}$

In August 2013, the board voted in favor of a distribution of $\$ 300$ million to the shareholders. ${ }^{202}$ In addition, on June 23, 2014, Arthur T. and two other officers were fired by the DSM board of directors. The board appointed Felicia Thornton and James Gooch to replace them. ${ }^{203}$

When the board of directors fired Arthur T., the employees responded with a greatly increased campaign to put their boss back into office. ${ }^{204}$ By June 25, 2014, days after Arthur T. was fired, seven executives quit their jobs to protest his firing. ${ }^{205}$ More information and testimonials appeared on the Facebook page "Save the Market Basket," which had been created the year before. ${ }^{206}$ Similarly, the website "We Are Market Basket," which had been created the year before, became very active. ${ }^{207}$ In July, employees at the Market Basket store in Burlington, Massachusetts led the way by handing out "We are Market Basket and we need your help" pamphlets to customers. ${ }^{208}$ Also in July, the employees at the Market Basket store

\footnotetext{
meeting. Cowan did not at that time propose replacing Arthur T. as president [and CEO], or otherwise changing management personnel. 
in Tewksbury, Massachusetts, where DSM is based, demanded that the company rehire Arthur T. as chief executive officer. ${ }^{209}$ On July 18, 2014, "We Are Market Basket" held its first rally demanding that the company rehire Arthur T., and asked others to support their efforts. ${ }^{210}$ Employees at Market Basket stores around Massachusetts stopped working to boycott Arthur T.'s removal. ${ }^{211}$ Customer traffic significantly declined. ${ }^{212}$

Toward the end of July 2014, Arthur T. released a statement asking DSM to hire back the employees. ${ }^{213}$ His side of the family announced its interest to buy out the other side of the family of their DSM shares. ${ }^{214}$ The board of directors met to consider the Class B shareholders' offer and other options. ${ }^{215}$ While the board of directors mulled over its options, "We Are Market Basket" held its third rally in Tewksbury. ${ }^{216}$ On July 30, 2014, Felicia Thornton and Jams Gooch demanded that boycotting employees return to work by August $4 .^{217}$ On Sunday, August 3, Arthur T. issued a statement that he was ready to return to his position of CEO to restore the business. ${ }^{218}$ On August 4, the deadline for boycotting employees, DSM held a job fair for potential job applicants. ${ }^{219}$ The turnout was low. ${ }^{220}$ On August 5, "We Are Market Basket" held its fourth rally in Tewksbury. ${ }^{221}$ During this time, Market Basket stores had meager provisions on the shelves. ${ }^{222}$ Employees picketed in front of the stores, encouraging consumers to shop elsewhere to support efforts

\footnotetext{
209. Id.

210. Kasperkevic, supra note 191.

211. Id.

212. Katharine Q. Seelye \& Michael J. de la Merced, Grocery Chain Reels as Employees and Customers Rally for an Ousted President, N.Y. Times (Aug. 6, 2014), http://www.nytimes.com/2014/08/06/us/grocery-chain-reels-as-employees-and -customers-rally-for-an-ousted-president.html?_r=0.

213. Id.

214. Id.

215. Id.

216. Id.

217. Id.

218. Id.

219. Id.

220. Casey Ross et al., Market Basket Vows to Replace Dissident Workers, Bos. GLOBE (July 31, 2014), https://www.bostonglobe.com/business/2014/07/30 /arthurs/pHOF5ySLsjQusOWEQ3HwNP/story.html.

221. Id.

222. Id.
} 
to reinstate Arthur T. ${ }^{223}$ There was concern that boycotting employees would be fired or, otherwise, retaliated against. ${ }^{224}$

On August 7, 2014, Massachusetts' Attorney General Martha Coakley published "a hotline for Market Basket employees." ${ }^{225}$ The next day Massachusetts Governor Deval Patrick wrote a letter to DSM's board of directors urging that they resolve the issue soon. ${ }^{226}$ " $[\mathrm{F}]$ ailure to resolve this matter is not only hurting the company's brand and business, but also many innocent and relatively powerless workers whose livelihoods depend on you."227 The board of directors indicated that it invited Arthur T. back to DSM, but not into the position from which he was fired. ${ }^{228}$

On August 9, 2014, Arthur S. issued a statement indicating that he would sell his shares to Arthur T. and provide a loan to Arthur T. to do the buy, but "on his own terms." T.'s "conduct to date" undermined the company. ${ }^{230}$ In response, Arthur T. issued a statement that he did not want to negotiate the deal in the press. ${ }^{231}$ The three independent directors on the board issued a statement that boycotting workers should get back to work to "end this zero sum game and act in the best interest of our associates, customers-and in the end, our company.",232

On August 14, 2014, Governor Deval Patrick issued a statement that he spoke with DSM's board of directors and Arthur $\mathrm{T} .{ }^{233}$ He said they were working on a deal. ${ }^{234}$ Governor Patrick asked the boycotting employees to go back to work. ${ }^{235}$ Later that month, DSM restored Arthur T. to his position as CEO, and Arthur T. reached a $\$ 1.5$ billion deal to buy the $50.5 \%$ of shares owned by the Class A shareholders. ${ }^{236}$ By this time, demonstrations and boycotts

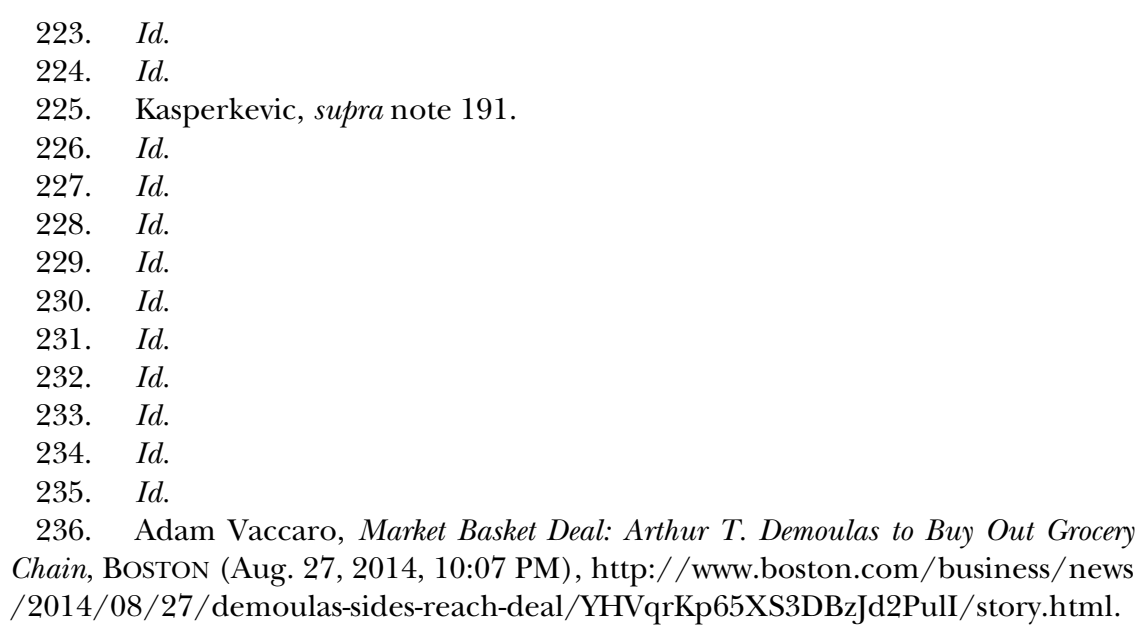


had caused inactivity in most of the seventy stores in the DSM chain. $^{237}$

What is this effect? From a small community and local business governance standpoint, it is a tool. It is the force from within. Local people who are employed at the big company or who frequent the big company for business have power if they act cohesively. To this end, the big business is well advised to keep its employees and consumers happy.

Theories of corporate social responsibility set forth the "enlightened self-interest model," which holds that those businesses that participate in and support their local communities will experience success. ${ }^{238}$ Some studies have also shown that local merchandisers generate greater benefits for local communities than do big companies. ${ }^{239}$ Conduct and decision making of larger businesses derives from the nature of the business beast, corporate or otherwise. ${ }^{240}$ The big business is set up to achieve profit maximization for the owners. However, through the enlightened self-interest model, by committing to supporting the local community, larger companies may make a governance decision that is not one that on its face sacrifices profit for the good of the community, as long as there is payback. ${ }^{241}$

The theory of enlightened self-interest points out that a big business' socially responsible behavior provides a channel to directly enhance those business' public image. ${ }^{242}$ Better public

237. The Rebirth of Stakeholder Capitalism?, supra note 205.

The directors of "Market Basket" are now considering selling the company. Arthur T. has made a bid, but other bidders have offered more. Reportedly, some prospective bidders think they can squeeze more profits out of the company than Arthur T. did. But Arthur T. may have known something about how to run a business that made it successful in a larger sense.

Id.

238. Terry L. Besser, Community Involvement and the Perception of Success Among Small Business Operators in Small Towns, 37 J. Small Bus. Mgmt. 16, 16 (1999).

239. Stacy Mitchell, Key Studies: Why Local Matters, InST. Loc. SELF-ReLiance (Dec. 22, 2011), https://ilsr.org/key-studies-why-local-matters.

240. HALEBSKY, supra note 2, at 5 ("The behavior of the corporation is related to its peculiar organizational characteristics, which are both a cause and a consequence of its size.”).

241. Lynn MacDonald, Examples of Enlightened Self-Interest in Business, Hous. CHRON., http://smallbusiness.chron.com/examples-enlightened-selfinterest -business-22880.html (last visited May 30, 2016).

242. Id. 
image means an increased chance that local customers and employees will purchase items from a business, that banks will give them "attractive rates" for loans, that suppliers will be fair, and that collaborators will "seek[] it out as partners on lucrative ventures." ${ }^{243}$ Constructively, this argument holds that employees within the big business are ensured to receive livable wages and other positive treatments, and consumers remain happy with purchases and the ethos of the big business. ${ }^{244}$ The big business gains by increased reputation-linked sales and the small community gains by the power it gains from having a force from within. The local community, through collaboration, ensures that this happens through planning, ordinances, and regulations. As discussed above, the push for zoning, minimum wage and benefit requirements, and customer services benefits the community in and of itself. ${ }^{245}$ In addition, it establishes an additional tool for locally grown employees and consumers who will act.

\section{CONCLUSION}

Impacts of the big fish coming to the small sea cannot be labeled as completely destructive to the community or to local business. Instead, the impact is a hazy picture. The small community, however, should act proactively to manage the situation to its advantage. Additionally, local businesses have much to gain by taking steps to ensure that the impact heads in a positive direction. Key to this success is staying vigilant, as well as understanding approaches and available tools that have worked for other communities.

This article has set forth the landscape of the small communities and characteristics of the big businesses. In particular, its analysis of studies shows that the impact of big businesses on small communities can become a force that is not all bad and that can be managed. Further, this article presents recommendations that the small community and local businesses should follow, in order to prepare and implement a strategy to deal with the big fish, most notably, being flexible and efficient in order to work together; collaborating between business and administrators; forming a guild; and using the tools previously mentioned. The power of the

243. Besser, supra note 238, at 17.

244. See supra Section III.A.2.

245. See supra Sections III.A.1-.3. 
employees working at the big company and of the customers shopping there embodies a stealth tool that showed its true colors in the summer of 2013 with Market Basket. This article urges small communities, particularly local businesses, to proactively ensure that this tool could be used in the future-ensuring well-treated employees and happy customers. Through tools, such as ordinances and regulations, the small fish may be able to ensure that when the boat gets rocked by the big fish, employees and customers can bond together to benefit the small sea from which they come. 